\title{
Activated sludge bacterial communities of typical wastewater treatment plants: distinct genera identification and metabolic potential differential analysis
}

\author{
Bo Zhang ${ }^{1} \mathbb{B}$, Xiangyang $\mathrm{Xu}^{1,2}$ and Liang Zhu ${ }^{1,2^{*}}$
}

\begin{abstract}
To investigate the differences in activated sludge microbial communities of different wastewater treatment plants (WWTPs) and understand their metabolic potentials, we sampled sludge from every biological treatment unit of 5 full-scale waste water treatment systems in 3 typical Chinese municipal WWTPs. The microbial communities and overall metabolic patterns were not only affected by influent characteristics but also varied between different biological treatment units. Distinct genera in different wastewater treatment systems were identified. The important microorganisms in domestic sewage treatment systems were unclassified SHA-20, Caldilinea, Dechloromonas, and unclassified genera from Rhodospirilaceae and Caldilineaceae. The important microorganisms in dyeing wastewater treatment systems were Nitrospira, Sphingobacteriales, Thiobacillus, Sinobacteraceae and Comamonadaceae. Compared with the obvious differences in microbial community composition, the metabolic potential showed no significant differences.
\end{abstract}

Keywords: Activated sludge, High throughput sequence, Textile dyeing wastewater, Metagenomic, Metabolic potential

\section{Introduction}

Textile dyeing and fine chemical industries have a prominent focus in certain areas of eastern China. From these, a large amount of industrial wastewater is discharged into local industrial zone WWTPs after simple pretreatments. This type of inflow adds pressure to the normal operation of local WWTPs due to the existence of refractory organic substances (e.g., chemical synthetic dyestuff, auxiliary assistants and other chemicals). But similar to domestic sewage, the industrial effluents require biological treatment for effective removal of the organic pollutants (Orhon et al. 2009). The AS process is widely used biological treatment in all municipal-grade wastewater treatment plants due to its low operation cost (Wagner and Loy 2002). As the microorganisms in AS are the

\footnotetext{
${ }^{*}$ Correspondence: felix79cn@hotmail.com

${ }^{1}$ Department of Environmental Engineering, Zhejiang University,

Hangzhou 310058, People's Republic of China

Full list of author information is available at the end of the article
}

main contributors for pollutant removal, identify the functional microbes would be helpful to improve WWTP performace (Liang et al. 2014).

Many methods have been developed to investigate and characterize the microbial communities. Including cultivation based methods, traditional molecular biotechnological techniques (Zielinska et al. 2016; Yang et al. 2011) and more advanced high-throughput sequencing technology (Ye et al. 2012; Roesch et al. 2007; Qian et al. 2011; Claesson et al. 2009; Fierer et al. 2008). In one key example, pyrosequencing of $16 \mathrm{~S}$ rRNA gene amplicons revealed a core bacterial community of 24 families and comparisons of summer and winter samples showed no significant differences in microbial community (Isazadeh et al. 2016). In another study using the Illumina HiSeq sequencing platform, 63 genera were identified as the core microbes in 13 Danish WWTPs during summer (August). Among of them, the genus Nitrotoga was thought to be the primary nitrite-oxidizer rather than Nitrospirae (Saunders et al. 2016). 
However, almost all the research about the AS microbial community of WWTPs has only focused upon one single system, usually represented as a municipal sewage treatment system (Chen et al. 2016; Flowers et al. 2013; $\mathrm{Hu}$ et al. 2012; Lanham et al. 2013; Ma et al. 2015; Mielczarek et al. 2013; Muszynski et al. 2015; Valentin-Vargas et al. 2012; Wan et al. 2011; Wang et al. 2012; Wells et al. 2011; Xu et al. 2017; Yang et al. 2011; Zhang et al. 2012; Zielinska et al. 2016). A comprehensive comparison of municipal sewage treatment systems and industrial wastewater treatment systems is scarcely.

In this study, 5 full-scale municipal wastewater treatment systems from 3 WWTPs were selected which mainly treated domestic sewage, textile dyeing and fine chemical industry wastewater, respectively. Microbial DNA was extracted from the sludge using a liquidnitrogen grinding pretreatment method. Metagenomic sequencing and bioinformatic analysis of the microbial communities was then carried out. The objectives were to understand the differences of the AS microbial communities and make a interpretation of their metabolic potentials as a basis for further research work.

\section{Materials and methods}

\section{Sample collection}

In this study, Qige WWTP, Shaoxing WWTP and Shangyu WWTP were selected for microbial community analysis. The average pollutant removal efficiency per month and influent characteristics for each of these
WWTPs are summarized in Table 1. Each AS sample was sampled three times in the summer of 2015 at the same sample site (different parts of the same tank), and then mixed together. Every mixed sludge sample was centrifuged ( $4500 \times g$, $5 \mathrm{~min}$, room temperature) and the supernatant removed. Samples were stored at $-80{ }^{\circ} \mathrm{C}$ prior to DNA extraction. The sample sites and environmental parameters are also shown in Table 2.

\section{DNA extraction}

In this study, High molecular weight community DNA was extracted by the freeze-grinding, SDS-based method and was purified using a commercialized DNA isolation kit (e.g. E.Z.N.A., Omega, Norcross, Georgia, US) (Zhang et al. 2017). Following DNA extraction, the integrity of the DNA was tested using gel electrophoresis, and concentration and purity were determined using a Qubit Fluorometer (Thermo, USA). Then 16S rRNA based sequencing and metagenomic sequencing were conducted consequently.

\section{$16 \mathrm{~S}$ based high-throughput sequencing and data analysis}

The V3-V4 hypervariable region of the 16S rRNA genes was amplified by primer set 340F (5'-CCTACGGGNBGCASCAG-3') and 806R (5'-GGACTACNVGGGTAT CTAAT-3') (Fadrosh et al. 2014; Murphy et al. 2010). A $50-\mu \mathrm{L}$ PCR reaction system was performed for each amplification using a Phusion high-fidelity PCR master

Table 1 The influent and effluent water qualities of WWTPs

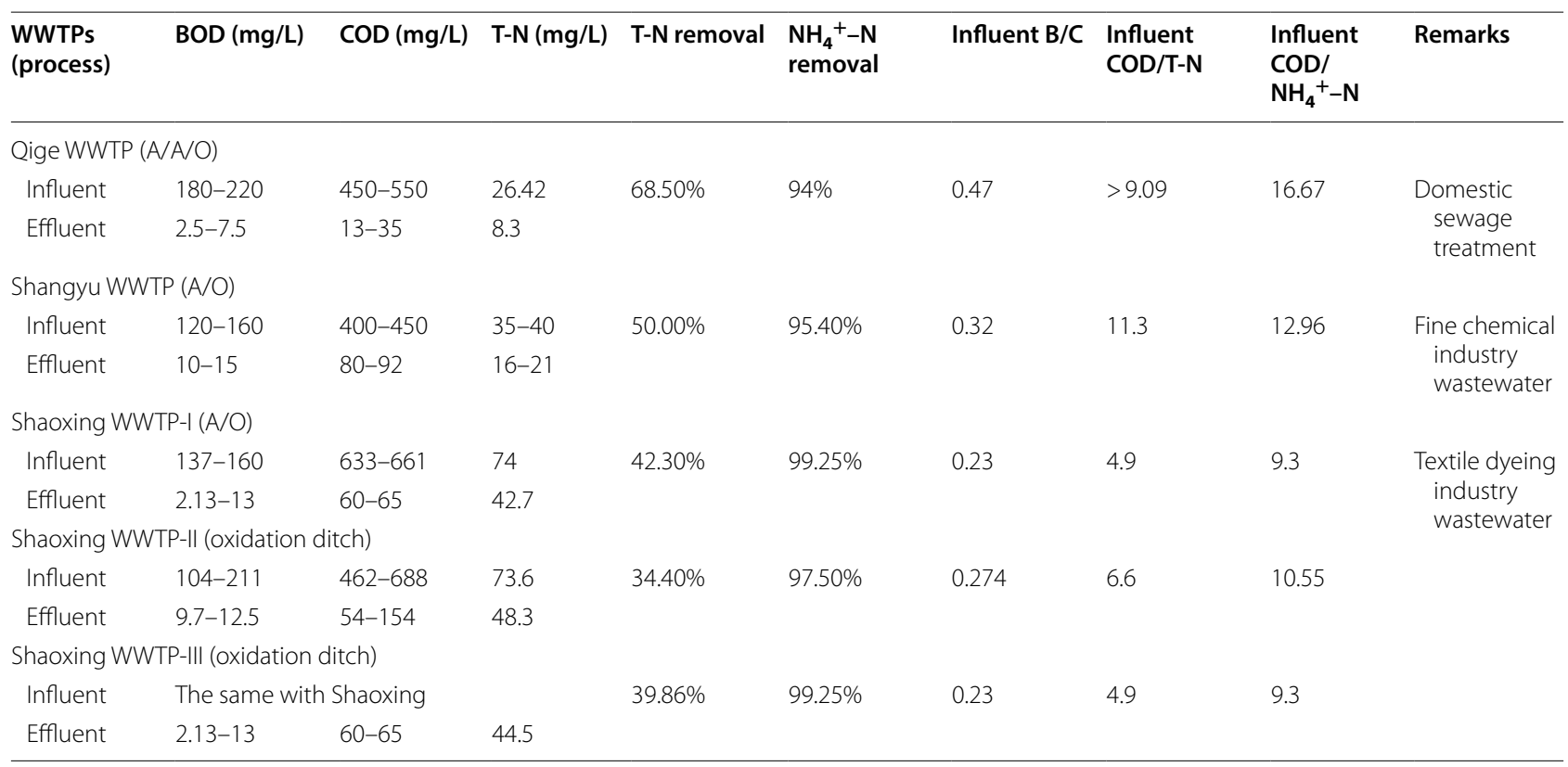


Table 2 Description of samples collected and important WWTP parameters

\begin{tabular}{|c|c|c|c|c|c|c|c|c|c|}
\hline Date & \multicolumn{3}{|l|}{ 2015/8/15 } & \multicolumn{2}{|l|}{ 2015/8/17 } & \multicolumn{4}{|l|}{ 2015/8/18 } \\
\hline $\begin{array}{l}\text { Temperature } \\
\left({ }^{\circ} \mathrm{C}\right)\end{array}$ & 28 & & & \multicolumn{2}{|l|}{32} & \multicolumn{2}{|l|}{32} & 32 & 32 \\
\hline WWTP name & Qige WWTP & & & \multicolumn{2}{|l|}{ Shangyu WWTP } & \multicolumn{2}{|c|}{ Shaoxing WWTP I } & $\begin{array}{l}\text { Shaoxing } \\
\text { WWTP-II }\end{array}$ & $\begin{array}{l}\text { Shaoxing } \\
\text { WWTP- } \\
\text { III }\end{array}$ \\
\hline Sampling site & $\begin{array}{l}\text { Anaerobic } \\
\text { tank }\end{array}$ & Anoxic tank & Aeration tank & $\begin{array}{l}\text { Anaerobic } \\
\text { tank }\end{array}$ & Aeration tank & $\begin{array}{l}\text { Anaerobic } \\
\text { tank }\end{array}$ & Aeration tank & $\begin{array}{l}\text { Oxidation } \\
\text { ditch }\end{array}$ & $\begin{array}{l}\text { Oxidation } \\
\text { ditch }\end{array}$ \\
\hline Code & QG-Ana & QG-Ano & QG-O & SY-A & SY-O & SX-1-A & SX-I-O & SX-II (OD) & SX-III (OD) \\
\hline $\begin{array}{l}\text { Valid tank } \\
\text { volume } \\
\left(\mathrm{m}^{3}\right)\end{array}$ & 5792 & 22,010 & 43,443 & 9640 & 36,730 & 44,640 & 216,691 & 818,670 & 302,000 \\
\hline $\begin{array}{l}\text { Hydraulic } \\
\text { retention } \\
\text { time }(h)\end{array}$ & 1 & 3.8 & 7.5 & 4.11 & 15.67 & 8.5 & 15 & 43.6 & 40.3 \\
\hline $\begin{array}{l}\text { Sludge reten- } \\
\text { tion time } \\
\text { (days) }\end{array}$ & $15-18$ & & & $6-14$ & & $15-22$ & & $10-17$ & \\
\hline $\begin{array}{l}\text { pH value on } \\
\text { sample }\end{array}$ & 7.5 & 7.4 & 7.21 & 8.18 & 7.92 & 7.49 & 7.62 & 7.3 & 7.9 \\
\hline
\end{tabular}

mix with a HF buffer. The amplification was conducted in an XP cycler (Bioer) as follows: Initial denaturation at $98{ }^{\circ} \mathrm{C}$ for $30 \mathrm{~s}$; 30 cycles at $98{ }^{\circ} \mathrm{C}$ for $15 \mathrm{~s}, 50{ }^{\circ} \mathrm{C}$ for $15 \mathrm{~s}$, and $72{ }^{\circ} \mathrm{C}$ for $15 \mathrm{~s}$; with a final extension at $72{ }^{\circ} \mathrm{C}$ for $1 \mathrm{~min}$. Each $50 \mu \mathrm{L}$ of PCR mixture contained $25 \mu \mathrm{L}$ of PCR mix buffer, $3 \mu \mathrm{L}$ of DMSO, $1 \mu \mathrm{M}$ primer, $3 \mu \mathrm{L}$ of each dNTP and $10 \mu \mathrm{L}$ of genomic DNA. Nuclease free water was added up to $50 \mu \mathrm{L}$. The PCR products were separated by $2 \%$ agarose gel electrophoresis $(6 \mathrm{v} / \mathrm{cm})$. The bands of the expected sizes were purified using an AXYGEN gel extraction kit (AP-GX-250G, AXYGEN) following the manufacturer's instructions. The sample DNA was sequenced using an Illumina MiSeq desktop sequencer $(2 \times 300$ bp paired-end run, San Diego, CA) according to standard protocols. The sequence read processing was performed using QIIME (version 1.9.0) with the following quality control criteria: 1) removal of reads with ambiguous nucleotides; 2) removal of reads of less than $150 \mathrm{bp}$; 3) removal of reads containing homopolymers of $\geq 6 \mathrm{bp}$; 4 ) the establishment of a quality window of $50 \mathrm{bp}$ with an average flowgram score of 25 (Caporaso et al. 2010). The sequences have been deposited in the NCBI Short Read Archive under accession number: SRP110572 (SRX2972725-SRX2972734).

The reads were then assigned to their corresponding samples according to their barcodes, denoised using Denoiser (Reeder and Knight 2010), clustered using uclust (Edgar 2010), and then assigned to their operational taxonomic units (OTUs) at 3\% dissimilarity. The most abundant reads were selected as representatives from each OTU for de novo alignment using MUSCLE and alignment against the Greengene v13_8 database using QIIME (Edgar 2004). The species diversity, richness, and rarefaction curves were computed at 3\% dissimilarity as part of the QIIME alpha diversity and beta diversity pipeline. The beta diversity was analyzed after rarefying the samples in the smallest-sized library using a step size of 100 with 100 repetitions per step. Principal-coordinate analysis (PCoA) was performed in the $\mathrm{R}$ environment using the vegan package. To identify the dominant/distinct genera, the genus level box plot of multiple groups was generated by STAMP through the two-sided Welch's exact test and excluded any genus which had a low effect size of a proportions ratio $(<2)$ and difference between proportions $(<1)$.

\section{Library preparation, metagenomic sequencing}

Illumina shotgun DNA library construction and sequencing was conducted by the Beijing Genomic Institute at Shenzhen, China. Specifically, after fragmentation, paired end fragment library in length of $\sim 170$ bp was constructed. Adaptor-appended fragments were sequenced on Illumina MiSeq desktop sequencer $(2 \times 300$ bp pairedend run, San Diego, CA) according to standard protocols.

Reads of average length of $90 \mathrm{bp}$ for each end were generated. Reads were excluded from further analysis if they were shorter than $35 \mathrm{bp}$, had more than 3 ambiguous nucleotides, had 15 bp or more overlapping regions with adapter sequences, had more than 36 nucleotides with a quality value lower than 20 , or were potential duplicated reads from amplification artefacts. The sequences were deposited to the Metagenomics RAST (MGRAST) sever with accession numbers PRJNA391055. 


\section{Read assembly and gene prediction}

The cleaned sequence reads were assembled into contigs using SOAP denovo ( $\mathrm{v} 2.04$, with settings of $-\mathrm{d}$ $1,-\mathrm{M} 3,-\mathrm{R},-\mathrm{u},-\mathrm{F})$. Only contigs longer than $500 \mathrm{bp}$ were used for further analysis. Open reading frames (ORFs) were predicted from contigs using MetaGeneMark (version 3.38) using default settings. The predicted ORFs longer than $100 \mathrm{nt}$ were translated into protein sequences based on the NCBI translation table 11. CD-HIT (version 4.7) was then used to remove 'redundant' (or highly similar) sequences and to determine gene abundance and statistics.

\section{Function annotation}

None-redundant protein sequences of the predicted genes were used to search against the NCBI NR (17 Aug. 2017), eggNOG (version 4.5) and against the KEGG (28 Jul. 2017) databases using BLASTP with the E-value cut-off of $10^{-5}$. The abundance of a certain COG or KEGG entry in each sample was calculated by the total number of found genes weighted by their coverage. We searched gene function of nitrate/ nitrite reductase, nitric oxide reductase, nitronate monooxygenase, nitrogen fixation protein, nitrate/ nitrite transporter, hydroxylamine reductase, nitrous oxide reductase, periplasmic nitrate reductase, ammonia monooxygenase, ferredoxin-nitrite reductase, nitrate reductase alpha/beta, hydroxylamine oxidoreductase, formate-dependent nitrate reductase in the eggNOG, KEGG and NCBI NR database. Then, we obtained their abundance in our samples from the search results. The abundance of KEGG function of xenobiotic biodegradation and sulfur metabolism was also obtained from KEGG search results.

\section{Results}

Due to the presence of too much synthetic dye in the industrial wastewater treatment systems, the influent of the 3 full-scale WWTPs in Shaoxing and Shangyu WWTP usually contained a certain amount of sulfide and refractory organic pollutants. The specific organic pollutant in Shaoxing WWTP is reported as terephthalic acid (Yi et al. 2015), dyeing aids (e.g., anhydrous sodium sulfate), and acids (e.g., sulfuric acid) (Robinson et al. 2001). Comparatively, the performance of Qige WWTP had the best performance in COD, BOD and nitrogen removal which was ascribed to the better biodegradable in inflow. The highest COD removal rate was achieved in QigeWWTP (average 91.1\%), where the effluent consistently met the national Grade 1-B standard. The COD removal rate of Shangyu WWTP was the lowest (less than 77\%). The T-N removal rate for industrial wastewater treatment system (Shaoxing and Shangyu WWTPs) was not higher than 50\%, of which SX-II (OD) had the lowest $\mathrm{T}-\mathrm{N}$ removal rate (average 34\%). However, a highly stable $\mathrm{NH}_{3}-\mathrm{N}$ removal rate was demonstrated in all WWTPs. The detailed performance data for the summer is shown in Table 1.

\section{OTU analysis of sludge samples}

After quality assessment, with the removal of any sequence reads of less than $150 \mathrm{bp}$, a total of approximately 342097 sequence reads were obtained in this study (Table 3). The Shannon index of municipal WWTP was shown to be higher (the three samples from the Qige WWTP ranging from 8.9256 to 9.2775) than for the textile dyeing (the four samples from the Shaoxing WWTP ranging from 6.7722 to 8.117 ) and fine chemical industrial wastewater treatment systems (the two samples from the Shangyu WWTP being 6.2174 to 7.1181 ). As

Table 3 OTUs number and sequencing statistical tables

\begin{tabular}{|c|c|c|c|c|c|c|c|}
\hline Sample name & OTUs number & OTUs Seq & Coverage & Chao1 & Shannon (bit) & Ace & Simpson \\
\hline QG-Ana & 2565 & 11,799 & 0.88 & 3830.2709 & 8.9256 & 4280.8225 & 0.9881 \\
\hline QG-Ano & 3249 & 18,823 & 0.92 & 4057.4247 & 8.9634 & 4574.3833 & 0.9886 \\
\hline QG-O & 3419 & 17,254 & 0.9 & 4516.8361 & 9.2775 & 5072.5894 & 0.9916 \\
\hline SX-I-O & 2686 & 23,882 & 0.95 & 3621.9942 & 8.1170 & 3963.6947 & 0.9787 \\
\hline SX-I-A & 2779 & 24,805 & 0.96 & 3318.1739 & 7.9507 & 3695.3476 & 0.9800 \\
\hline SX-II(OD) & 3613 & 45,543 & 0.98 & 3702.4586 & 6.7722 & 4105.2816 & 0.8890 \\
\hline SX-III(OD) & 2302 & 21,430 & 0.95 & 2975.8851 & 7.1415 & 3346.1279 & 0.9587 \\
\hline SY-A & 1759 & 13,842 & 0.95 & 2101.0361 & 7.1181 & 2417.2464 & 0.9585 \\
\hline SY-O & 2264 & 25,262 & 0.96 & 2879.0802 & 6.2174 & 3241.7658 & 0.9258 \\
\hline
\end{tabular}

Chao1 and Shannon indexes, and sample coverage were calculated with Mothur at $97 \%$ similarity level

OTUs number, annotated operational taxonomic units number; OTUs Seq, raw operational taxonomic units sequences 
shannon index was used to measure microbial biodiversity (Schloss et al. 2011). So our results is accord with the previous conclusion that the taxonomic richness of municipal AS is greater than that of industrial AS (Ibarbalz et al. 2016).

\section{Microbial community similarity and morphologies of activated sludge}

Taxonomic assignment was based on the best achievable results of the RDP classifier with an $80 \%$ confidence threshold. PCoA analysis indicated that there was a clear delineation between groups at the taxonomic level (Fig. 1). The results showed that the microbial communities of each of the 9 samples could be clustered into 4 groups.

The lower "within group" distance indicate that influent composition impose a clear effect on microbial community composition (Fig. 2). In another aspects, the plants using $\mathrm{A} 2 \mathrm{O}$ or $\mathrm{A} / \mathrm{O}$ process are usually built with a number of successive tanks of the same type. Besides dissolved oxygen concentration (DO), this successive tanks don't really display any other differences. However, different and distinct microbes still can be found in the anaerobic tanks of these wastewater treatment systems (Fig. 3). So, DO is also a factor affecting microbial community composition. In this study, we found the distance between-group to be almost 2 times that of the distance within-group (Fig. 2). This implies that the effect of influent type on the microbial community is greater than the effect of dissolved oxygen.

Another factor that determines the group is process. The four samples from the Shaoxing WWTP are divided into two group samples (Group 2 and Group 3) in regard to the higher abundance of Proteobacteria in group 2.

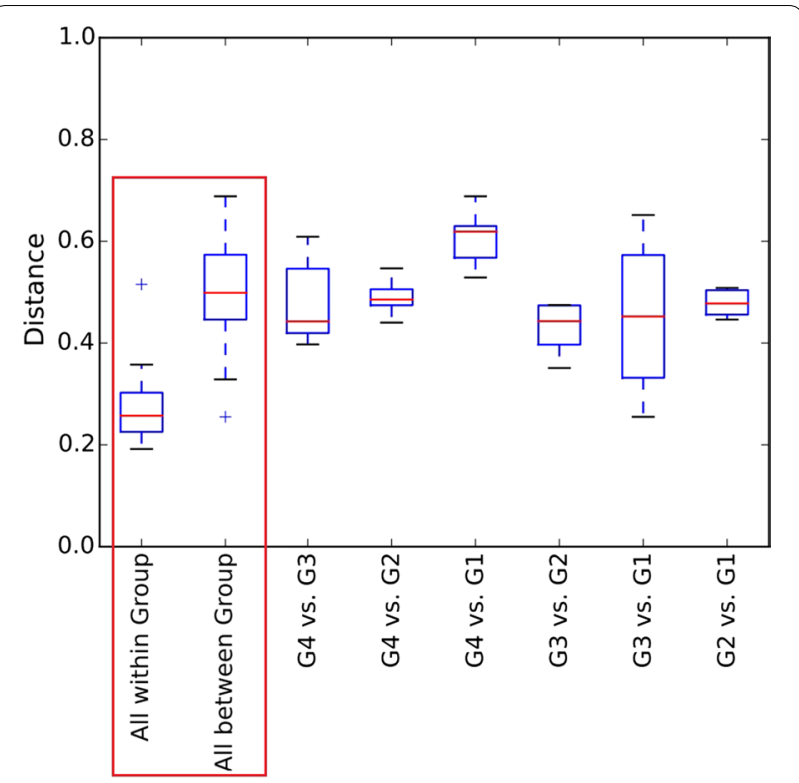

Fig. 2 Group distance. The tests of significance were performed using a two-sided Student's two-sample $t$ test

This might be ascribed to different processes as the two samples of group 2 were from Shaoxing WWTP-I which adopts $\mathrm{AO}$ processes whereas the samples of group 3 were from the carrousel oxidation ditches.

The morphologies of these AS were different in their colour (Fig. 4), SX-II(OD) and SX-III(OD) were reddishbrown in colour due to the presence of $\mathrm{Fe}^{3+}$.

\section{Bacterial community composition analysis}

As shown in Fig. 5, the dominant phyla in every sample included Proteobacteria (12.3-58.5\%), Acidobacteria (1.8-35.1\%), Chloroflexi (2.8-37.7\%) and Bacteroidia

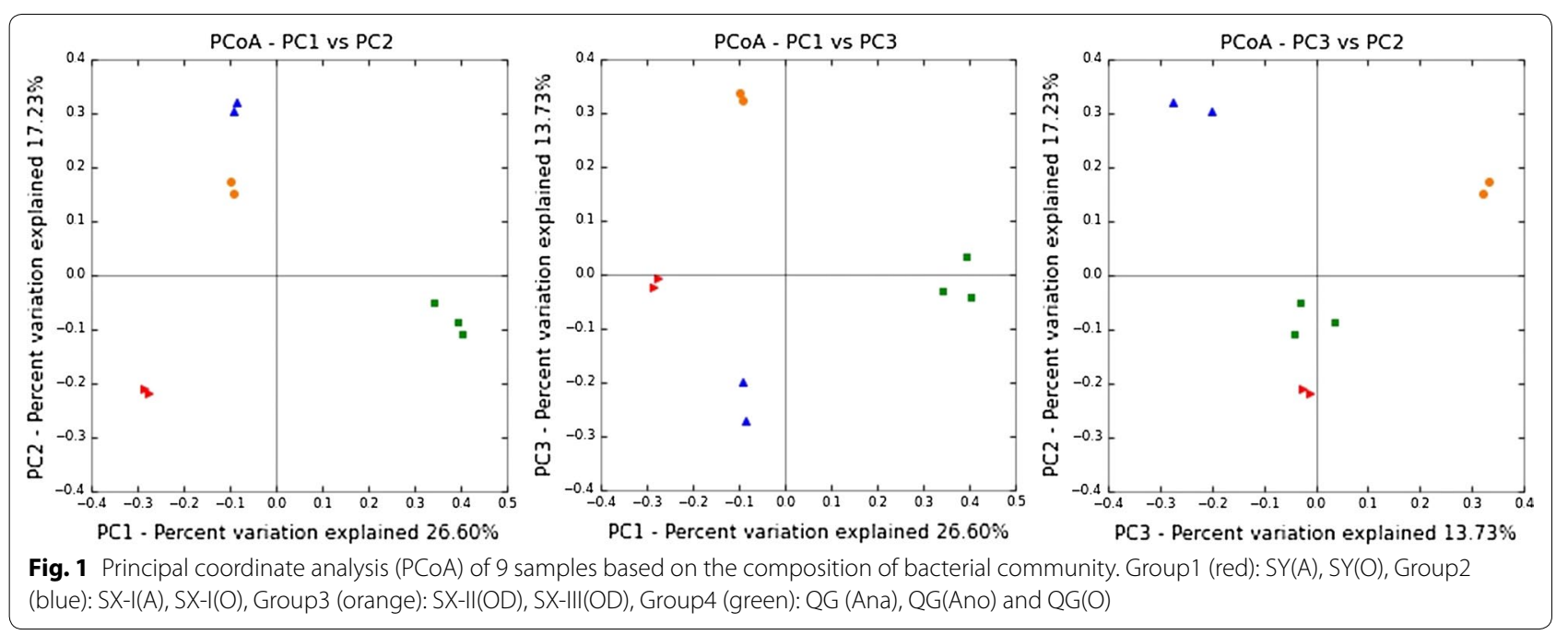




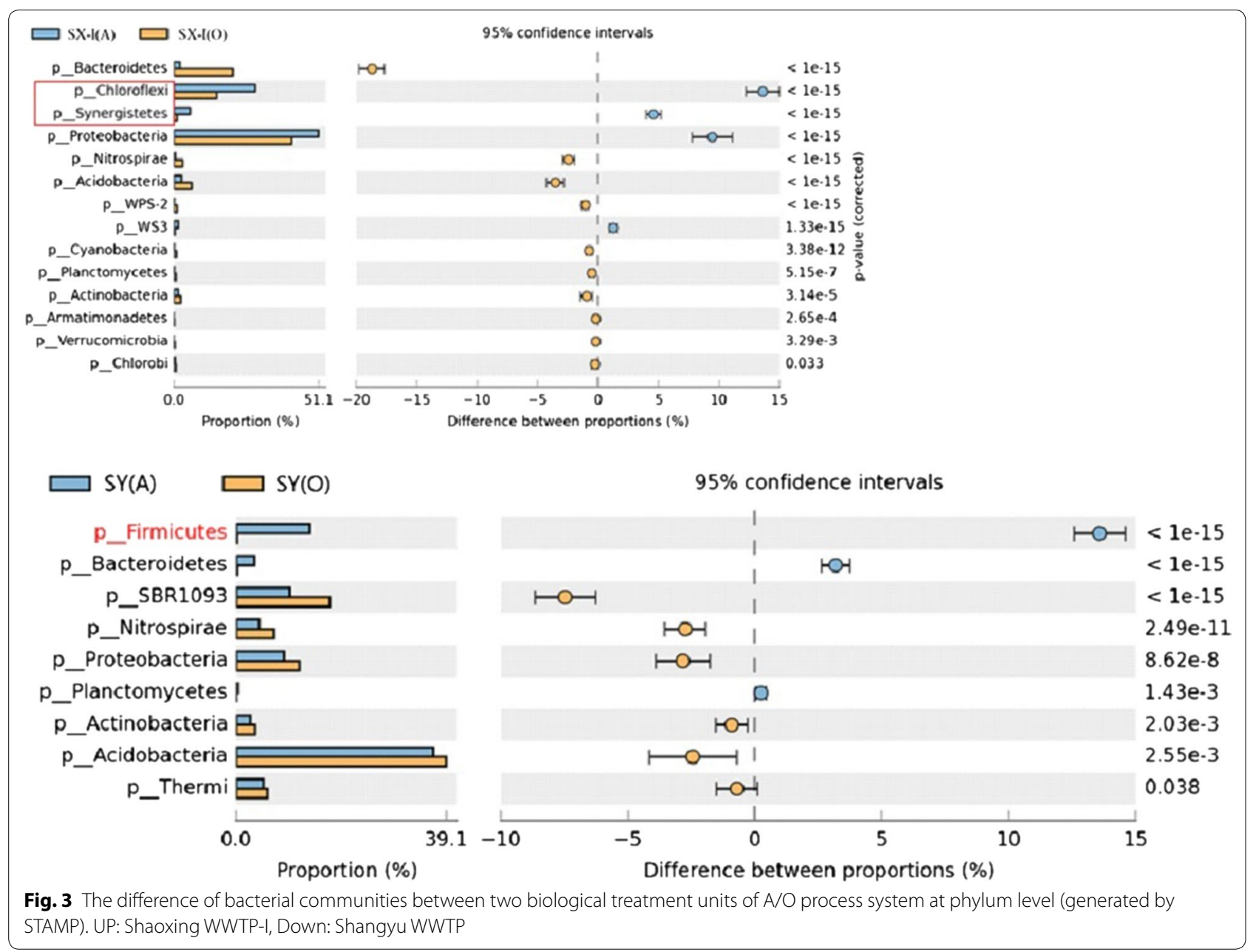

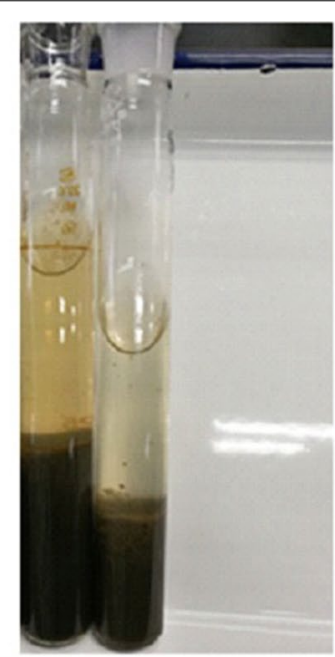

$S X-I(A) S X-1(0)$

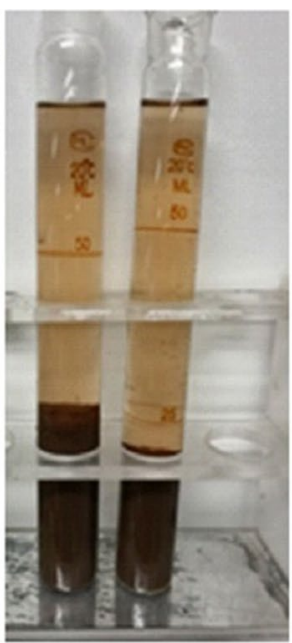

$S X-\|(O D) S X-I I(O D)$

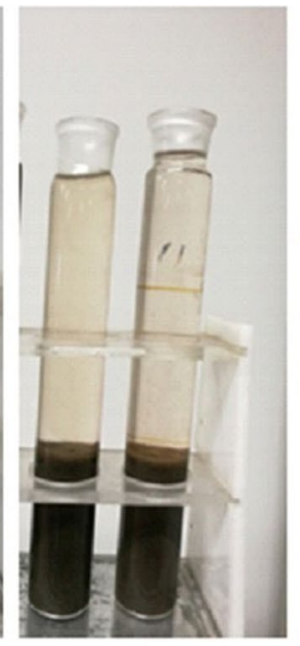

$S Y(A) \quad S Y(O)$

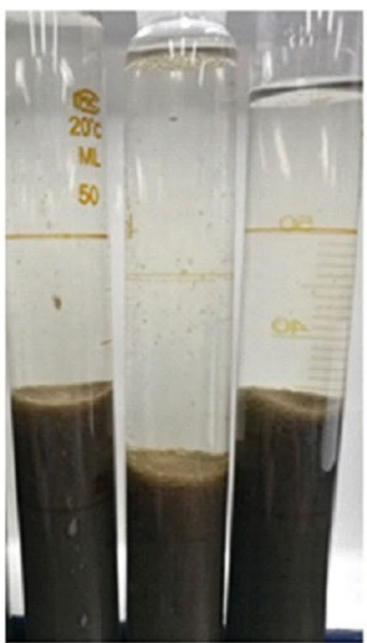

QG(Ano) QG (Ana) QG(O)

Fig. 4 Morphologies of activated sludge samples 


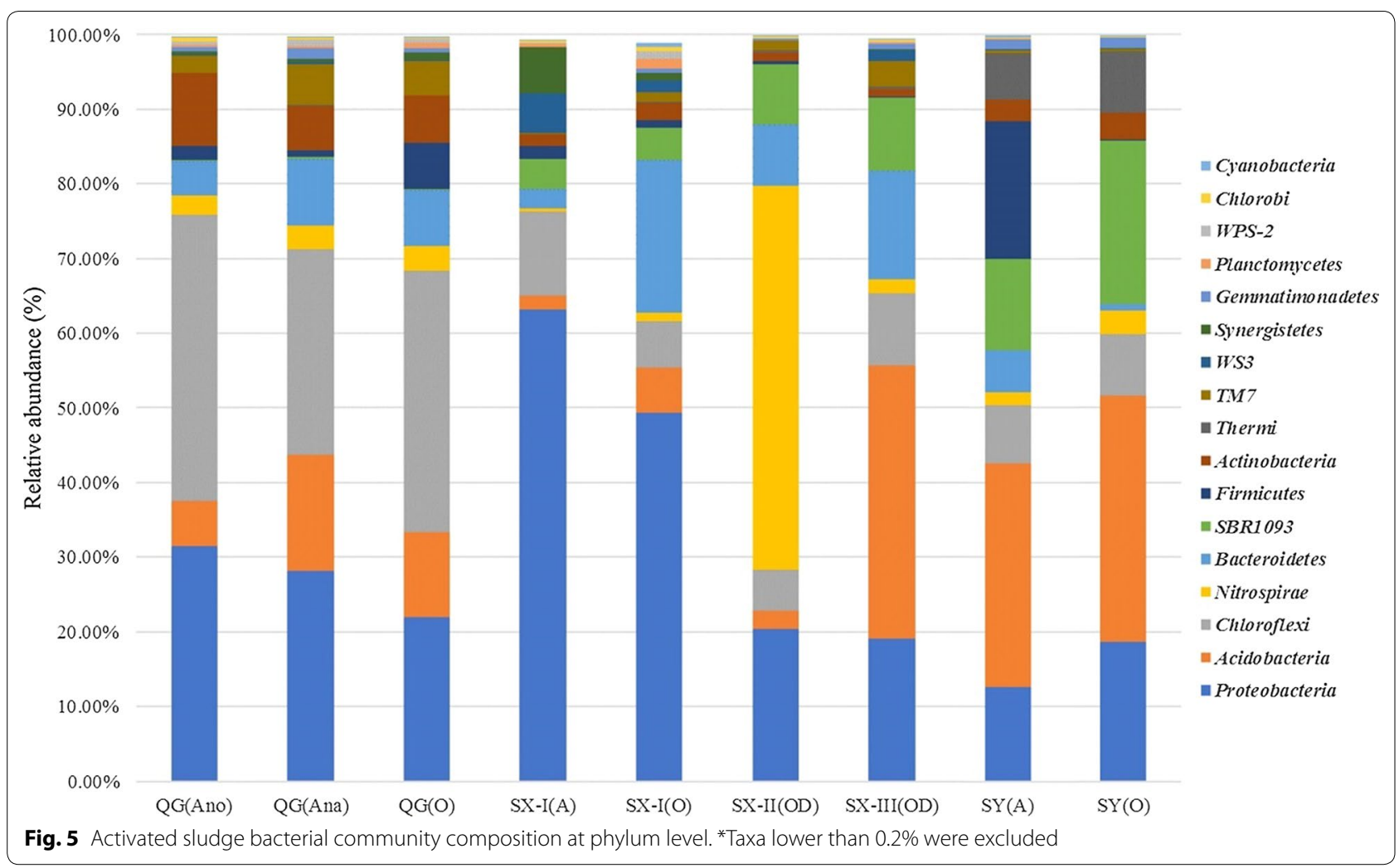

(0.7-19.2\%). This is consistent with previous studies on municipal WWTPs (Chen et al. 2016; Cydzik-Kwiatkowska and Zielinska 2016; Hien et al. 2011; Nielsen et al. 2010; Wan et al. 2011; Wang et al. 2012; Yang et al. 2011; Ye et al. 2012). In addition, Actinobacteria (0.7-6.8\%), TM7 (0.1-5.2\%), Synergistetes (0.02-5.6\%) and Thermi $(0.03-7.89 \%)$ were also present in every sample but not always as abundant organisms (Additional file 1).

Nitrospirae were particularly dominant in the bacterial community composition of the oxidation ditch in Shaoxing WWTP-II, accounting for $48.68 \%$. To the best of knowledge this is the highest content of Nitrospirae in any reported WWTP (Chen et al. 2016; Cydzik-Kwiatkowska and Zielinska 2016; Ma et al. 2015; Saunders et al. 2016; Xu et al. 2017; Ye et al. 2012; Zhang et al. 2012). It was also notable that the oxidation ditch of Shaoxing WWTP-III had abundant Acidobacteria (34.82\%).

The sludge samples from Shangyu WWTP mainly consisted of Acidobacteria, Proteobacteria, Candidatus phylum SBR1093, Chloroflexi and Thermi. Thermi has been found in geothermal springs all over the world and is known to be involved in $\mathrm{NH}_{4}{ }^{+}-\mathrm{N}$ removal (Coman et al. 2015; Liang et al. 2016; Panda et al. 2016; Paul et al. 2016). Due to the fact that industrial wastewater is usually discharged with an amount of heat, the influent temperature could hit $40{ }^{\circ} \mathrm{C}$ in summer. Thus, an abundance of Thermi should be associated with the typical influent of the Shangyu WWTP where high temperatures and appropriate organic substances in the influent have created an ideal external environment.

To identify the AS microbial community's composition in detail, the reads were further analyzed and assigned to a genus level (Additional file 2). Each WWTP could be characterized by its set of the most abundant or distinct genera. Combining this data with the WWTP performance in the summer of 2015 (Table 1), we will now discuss the dominant and/or distinct genera and parse their function related to pollutant removal.

\section{Discussion}

The dominant and distinct genera in the Qige WWTP included unclassified SHA-20, Caldilinea, Dechloromonas, and unclassified genera from Rhodospirilaceae and Caldilineaceae (Fig. 6a). Putting aside the unclassified genera, of the known genera the Caldilinea have been reported to include some filamentous species and play a role in forming flocs of AS in a wide range of WWTPs (Yoon et al. 2010). Caldilinea were represented from 8.16 to $10.83 \%$. Dechloromonas accounted for $1.67 \%$ in the anoxic tank. This genus is capable of reducing perchlorate and chlorate, which is associated with nitrate reductase (Achenbach et al. 2001). Moreover, 


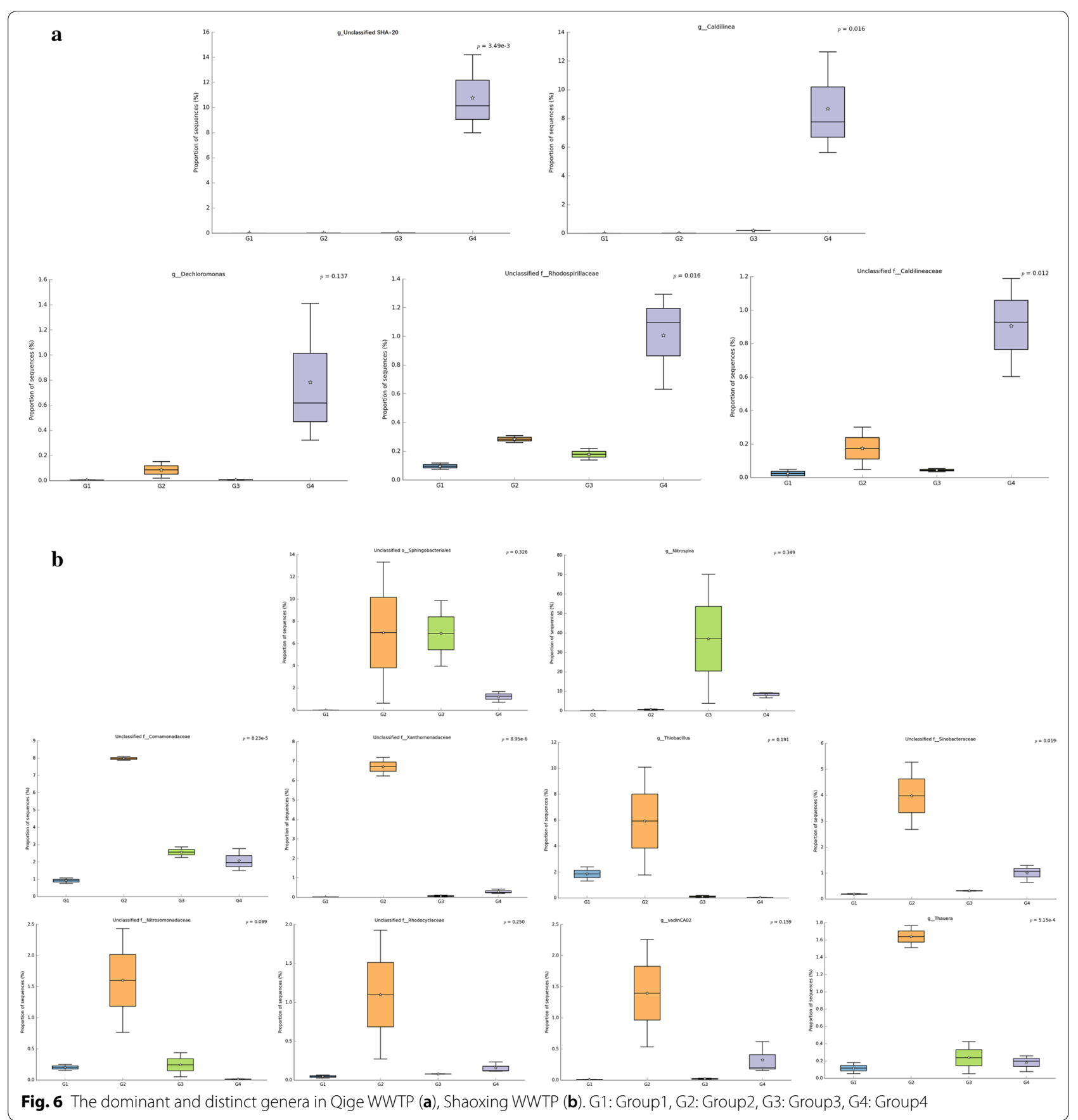

Dechloromonas is frequently reported as a phosphate accumulating organism in enhanced biological phosphorus removal reactors (Liu et al. 2005). As the AS in the Qige WWTP presented higher biodiversity, but most of the known genera represented lower than $1 \%$, so the potential functions of these genera require further investigation. Meanwhile, the functional redundancy contained in such a mix should enable the system to resist environmental perturbations and maintain stable COD,
$\mathrm{P}$, and $\mathrm{N}$ removal where some of the core genera can be replaced by others having the same functional role in AS. In this case there may be no need for some dominant genera to be present (Allison and Martiny 2008; Bradley and Pollard 2017; Johnson et al. 2015).

As mentioned in section 3.2, the WWTPs of Shaoxing are divided into two groups. As a whole, the dominant and distinct genus in the WWTPs of Shaoxing is an unclassified genus from Sphingobacteriales. The 
dominant and distinct genera of Group 2 included Thiobacillus, VadinCAO2, Thauera and unclassified genera from Comamonadacae, Xanthomonadacae, Sinobacteraceae, Nitrosomonadaceae and Rhodocyclaceae. The dominant and distinct genus of Group 3 is Nitrospira. The details can be seen in Fig. 6b. Sphingobacteriales has been reported to function as a BPA (bisphenol A) biodegradation bacterium (Oshiman et al. 2007). It could function as organic dyestuff degrader in an aerobic tank and provide monomer or oligomer carbon sources for Thiobacillus which can use non-organic carbon sources, such as $\mathrm{CO}_{3}^{2-}$ and $\mathrm{HCO}_{3}^{-}$. Thiobacillus and Thauera are all involved in aromatic compound degradation and denitrification conditions (Mao et al. 2010; Thomsen et al. 2007; Foss and Harder 1998; Shinoda et al. 2004; Zhang et al. 2015; Fernandez et al. 2009; Vishnivetskaya et al. 2013). Some strains from Comamonadaceae not only use phenol and their derivatives as energy sources but also act as a potential aerobic denitrifiers that directly transform ammonia into nitrogen under aerobic conditions $(\mathrm{Ni}$ et al. 2013). Xanthomonadaceae are obligate aerobes. Some of them have been directly or indirectly related to petroleum hydrocarbon degradation (MartinezLavanchy et al. 2015). Sinobacteraceae prefer to utilize aliphatic, aromatic hydrocarbon compounds and small organic acids for degradation (Gutierrez et al. 2013). They play crucial roles in the degradation of organic compounds and form the floc structure of AS (Khan et al. 2002; Shchegolkova et al. 2016). Nitrosomonadaceae is a well-known ammonia oxidizer (Black et al. 2017). Rhodocyclaceae and Xanthomonadaceae are reported to participate the simultaneous biodegradation of phenol and ammonia oxidation (Fitzgerald et al. 2015; Liu et al. 2017).

Due to the high dissolved oxygen concentration (3.0$5.0 \mathrm{mg} / \mathrm{L}$ ) in an oxidation ditch, the $\mathrm{NH}_{3}-\mathrm{N}$ removal rate is high. However, the nitrogen removal rate at Shaoxing WWTP II and III was lower than in others systems. This poor denitrification ability could be due to high nitrate accumulation. This might also account for the high abundant ammonia oxidizers and nitrifiers like Nitrosomonadaceae and Nitrospira (as above and see Additional file 2) (Daims et al. 2015). The reasons for the nitrate accumulation at Shaoxing WWTP II were the low $\mathrm{COD} / \mathrm{N}$ rate and the oxidation ditch process itself. Without a carbon source, the system cannot perform denitrification. Without anaerobic or anoxic units, the denitrification ability of ordinary denitrification bacteria would be inhibited regardless of the high dissolved oxygen concentration in the treatment system. Adding an enrichment culture of Thiosphaera, Pseudomonas, Alcaligenes, Paracoccus, Bacillus and Zoogloeal would be an ideal protocol for resolving this problem as these bacteria function as aerobic denitrifiers (Chen and Ni 2011; Ji et al. 2015).

The dominant/distinct genera of Shangyu WWTP are $B-42$ from the family Trueperaceae, Oscillospira, an unclassified genus from family Ellin6075, Nitrospiraceae, Microbacteriaceae, Ruminococcaceae, plus unclassified genus from class Vh5-B5-50 and TK17 (Fig. 7). Except for the most two distinct and dominant genera, unclassified genus from the family Ellin6075 order RB41 in Chloracidobacterium and unclassified genus from family $V H s-B 5-50$, the functions of which are still unknown to us. All the others microbes function in refractory organic degradation and nitrogen removal. Such as, Oscillspira was reported as involved in ferric reduction and/or high concentration dimethyl sulfide (DMS) degradation (Ye et al. 2016). Nitrospiraceae is known for its autotrophic nitrite oxidation and can be found in thermal underwater environments (Marks et al. 2012). Microbacteriaceae was reported that can grow in thermal underwater ecosystems and play important roles in denitrification (Sharma et al. 2017; Tomasek et al. 2017). And some Microbacteriaceae strains can even grow in a heavy metal contaminated environments (Corretto et al. 2017). Ruminococcaceae are able to produce mixed byproducts containing $\mathrm{H}_{2}$, ethanol, acetate and degrade Methyl tert-Butyl Ether (MTBE) (Liu et al. 2016; Veeravalli et al. 2017). Although we also know nothing about genus $B-42$, but as for Trueperaceae, it has been reported as a hydrocarbon-bearing microorganism where some strains from Trueperaceae have been seen to have the ability to grow under multiple extreme conditions such as high alkalinity, moderately salinity, high temperatures, and are even found $t o$ be present and remarkably resistant to ionizing radiation (Corretto et al. 2017; Qian et al. 2017). Additionally, Thiobacillus was also found $(1.49 \%$ in the anaerobic tank and $3.02 \%$ in the oxic tank). This result was perhaps due to the higher presence of chemical industrial wastewater influent at this plant.

Although many municipal and industrial WWTP have been analyzed using next generation sequencing (NGS). However, previous work about AS microbial community composition, were all done by extracting DNA with normal commercial isolation kit without properly considering the bias induced by the DNA extraction method. However, this bias had been clearly reported (Saunders et al. 2016). Furthermore, all the previous studies took aeration tank samples as if they were automatically representative of the whole WWTP and half of them used traditional molecular biotechnology (Chonova et al. 2016; Flowers et al. 2013; Hug et al. 2005; Jiang et al. 2016; Ju et al. 2014; Kim 2013; Muszynski et al. 2015; Tuncal et al. 2009; Wang et al. 2016). Again, most of the known research work only had its focus on municipal sewage 


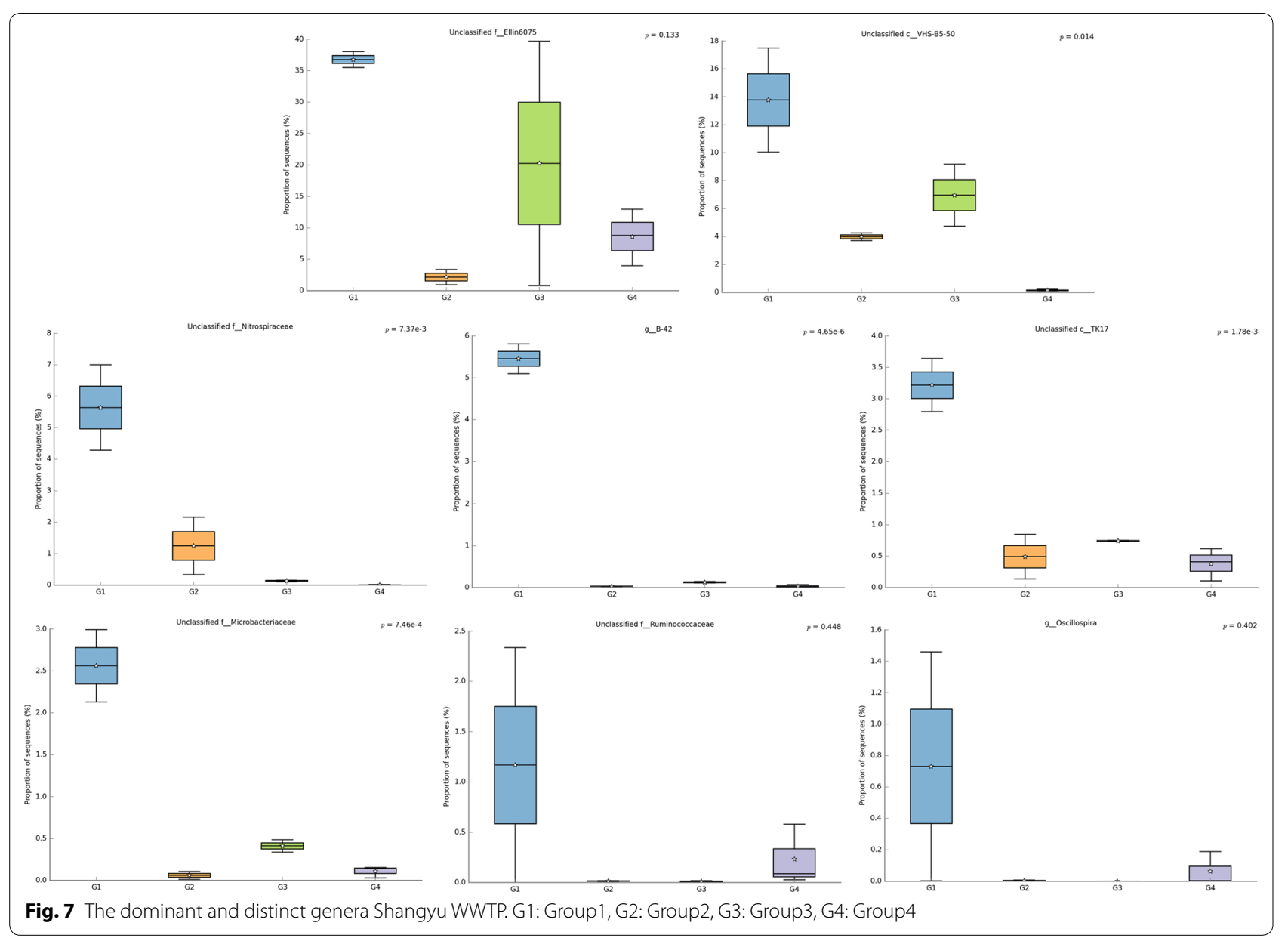

treatment systems (Chen et al. 2016; Cydzik-Kwiatkowska and Zielinska 2016; Ding et al. 2017; Isazadeh et al. 2016; Jiang et al. 2016; Jin et al. 2011; Ju et al. 2014; Lu et al. 2014; McLellan et al. 2010; Muszynski et al. 2015; Wan et al. 2011; Wang et al. 2016; Xu et al. 2017; Zhang et al. 2012; Zielinska et al. 2016). To make more comprehensive analysis on the AS microbial community of WWTP, samples were taken from every biological treatment unit of the specific industrial WWTPs with increased industrial inflow, not just the aeration tanks.

Kinetics of growth and decay are typically too slow to expect changes in community composition between AS from connected tanks of the same WWTP [e.g. SX-I(A)/ SX-I(O), SY(A)/SY(O), QG(Ana)/QG(Ano)/QG(O)]. To some extent, it is reasonable to consider the oxic tank AS sample as representative of $\mathrm{A} / \mathrm{O}$ and $\mathrm{A} 2 / \mathrm{O}$ process systems. The similarity analysis gives a clear empirical test for this positive association that has not been previously provided.

As presented by the research from Aalborg university, the concept of core community is useful to identify putatively important organisms (Saunders et al. 2016).
Compare with domestic sewage treatment system, distinct genera was more easier can be found in industrial wastewater treatment systems. The large scale of the textile dyeing industrial influents broadens the ecological amplitude of these aromatic compound degradation and denitrification bacteria which adapted to oligotrophic wastewater with low COD loading and perform the biodegradation of hazardous organic pollutants. The key functional genera of textile-dyeing industrial wastewater system would be Nitrospira, Sphingobacteriales, Thiobacillus, Sinobacteraceae and Comamonadaceae becomes reasonable.

The functional profile of the representative of four groups AS samples [QG(O), SX-I(O) SX-II(OD) and $\mathrm{SY}(\mathrm{O})$ ] were analyzed through metagenomic sequencing. Most of the genes were successfully classified into hierarchical metabolic categories using unscaled Manhattan variance distances and these are presented in a triplex hierarchical table (Additional file 3). The abundance of inferred genes from KEGG were generally lower than 1\% (Additional file 4), except for genes encoding transporters (ranging from 4.4 to $6.4 \%$ ) and 
ABC transporters (ranging from 2.7 to 4.7\%). Compared with the obvious bacterial community differences between groups, most of the effects of gene function in level 3 of KEGG were equally distributed within each of the groups. These inferences of metabolic functional genes did not show a consistent trend with the variation of the AS microbial community. In this way, a slow metabolic turnover between plants can be conceived. The reason why significant difference in microbial community but not in functional traits likely due to DNA nucleotide sequences was not as equivocal as phenotypic characters. All cells must produce proteins for their survival and eventual replication through transcribe the specific DNA into a single strand of messenger RNA, then this nucleotide sequence in mRNA is translated into a specific amino acid sequence of the protein. However, except for the essential functions in cells, most of gene expression were not conserved. To investigate their metabolic difference, functional profiles of these microbial consortia should be investigated through metatransgenomic analysis.

Considering excessive quantities of industrial inflow, we further investigated differences in xenobiotic biodegradation at the level 3 of KEEG. Comparatively, a distinctly high prediction of functional genes related to nitrotoluene degradation could be found in SX-II(OD). However, the proportion was still lower than $0.5 \%$ and presented with a high $P$ value $(0.573)$, which could be considered a non-significant difference. Difference were also evident in the individual genes related to nitrogen removal between samples based on the KEGG Orthology database with an acceptable $P$ value (lower than 0.05). However, the proportion was even less than $0.07 \%$ at the highest point. So, the bacterial communities from different wastewater treatment systems exhibited only minor metabolic potential differences.

\section{Additional files}

Additional file 1. The relative abundance of microbial communities at the phyla level.

Additional file 2. The relative abundance of microbial communities at the genus level.

Additional file 3. KEGG based triplex hierarchical metabolic pathway composition statistic table.

Additional file 4. KEGG based functional enzyme encoding gene composition statistic table.

\section{Abbreviations}

AS: activated sludge; WWTP: wastewater treatment plant; PCR: polymerase chain reaction; SDS: sodium dodecyl sulfate; BOD: biochemical oxygen demand; COD: chemical oxygen demand; T-N: total Kjeldhal nitrogen; $\mathrm{NH}_{3}-\mathrm{N}$ : ammonia nitrogen; T-P: total phosphorus; DMSO: dimethyl sulfoxide;
OTUs: operational taxonomic units; RDP: ribosomal database project; ACE: abundance based coverage estimator; A2O: anaerobic-anoxic-oxic process; OD: oxidation ditch process; AO: anaerobic-oxic process; PCoA: principal coordinate analysis; BPA: bisphenol A.

\section{Authors' contributions}

XX conceived and directed the project. BZ performed the research, analyzed data and wrote the main manuscript text. $L Z$ revised the manuscript text. All authors read and approved the final manuscript.

\section{Author details}

${ }^{1}$ Department of Environmental Engineering, Zhejiang University, Hangzhou 310058, People's Republic of China. ${ }^{2}$ Zhejiang Province Key Laboratory for Water Pollution Control and Environmental Safety, Hangzhou 310058, China.

\section{Acknowledgements}

We would like to thank Professor Lizong Zhu of Zhejiang University, Mr. Dan Yu, Huang cheng hua and manager Pan wei long for sludge sampling.

\section{Competing interests}

The authors declare that they have no competing interests.

\section{Availability of data and materials}

The data are included within the manuscript, and all data are fully available without restriction.

\section{Consent for publication}

This manuscript does not contain any individual person's data.

\section{Ethics approval and consent to participate}

This article does not contain any studies with human participants or animals performed by any of the authors.

\section{Funding}

This work was financially supported by the Zhejiang Province Science and Technology Projects (No. 2015C03010), the National Natural Science Foundation of China (No. 51478416) and the National Key Technologies Research and Development Program of China (No. 2013BAC16B04).

\section{Publisher's Note}

Springer Nature remains neutral with regard to jurisdictional claims in published maps and institutional affiliations.

Received: 30 March 2018 Accepted: 7 November 2018

Published online: 14 November 2018

\section{References}

Achenbach LA, Michaelidou U, Bruce RA, Fryman J, Coates JD (2001) Dechloromonas agitata gen. nov., sp nov and Dechlorosoma suillum gen. nov., sp nov., two novel environmentally dominant (per)chlorate-reducing bacteria and their phylogenetic position. Int J Syst Evol Microbiol 51:527-533

Allison SD, Martiny JBH (2008) Resistance, resilience, and redundancy in microbial communities. Proc Natl Acad Sci USA 105:11512-11519. https://doi. org/10.1073/pnas.0801925105

Black EM, Chimentf MS, Just CL (2017) Effect of freshwater mussels on the vertical distribution of anaerobic ammonia oxidizers and other nitrogentransforming microorganisms in upper Mississippi river sediment. PEERJ 5:33. https://doi.org/10.7717/peerj.3536

Bradley PH, Pollard KS (2017) Proteobacteria explain significant functional variability in the human gut microbiome. Microbiome 5:23. https://doi. org/10.1186/s40168-017-0244-z

Caporaso JG, Kuczynski J, Stombaugh J, Bittinger K, Bushman FD, Costello EK, Fierer N, Pena AG, Goodrich JK, Gordon Jl, Huttley GA, Kelley ST, Knights D, Koenig JE, Ley RE, Lozupone CA, McDonald D, Muegge BD, Pirrung M, Reeder J, Sevinsky JR, Tumbaugh PJ, Walters WA, Widmann J, Yatsunenko T, Zaneveld J, Knight R (2010) QIIME allows analysis of high-throughput 
community sequencing data. Nat Methods 7(5):335-336. https://doi. org/10.1038/nmeth.f.303

Chen Q, Ni JR (2011) Heterotrophic nitrification-aerobic denitrification by novel isolated bacteria. J Ind Microbiol Biotechnol 38(9):1305-1310. https ://doi.org/10.1007/s10295-010-0911-6

Chen YS, Zhao Z, Peng YK, Li J, Xiao L, Yang LY (2016) Performance of a full-scale modified anaerobic/anoxic/oxic process: high-throughput sequence analysis of its microbial structures and their community functions. Bioresour Technol 220:225-232. https://doi.org/10.1016/j.biort ech.2016.07.095

Chonova T, Keck F, Labanowski J, Montuelle B, Rimet F, Bouchez A (2016) Separate treatment of hospital and urban wastewaters: a real scale comparison of effluents and their effect on microbial communities. Sci Total Environ 542:965-975. https://doi.org/10.1016/j.scitotenv.2015.10.161

Claesson MJ, O'Sullivan O, Wang Q, Nikkila J, Marchesi JR, Smidt H, de Vos WM, Ross RP, O'Toole PW (2009) Comparative analysis of pyrosequencing and a phylogenetic microarray for exploring microbial community structures in the human distal intestine. PLoS ONE 4(8):15. https://doi.org/10.1371/ journal.pone.0006669

Coman C, Chiriac CM, Robeson MS, Ionescu C, Dragos N, Barbu-Tudoran L, Andrei AS, Banciu HL, Sicora C, Podar M (2015) Structure, mineralogy, and microbial diversity of geothermal spring microbialites associated with a deep oil drilling in Romania. Front Microbiol 6:14. https://doi. org/10.3389/fmicb.2015.00253

Corretto E, Antonielli L, Sessitsch A, Compant S, Hofer C, Puschenreiter M, Brader $G$ (2017) Complete genome sequence of the heavy metal resistant bacterium Agromyces aureus AR33(T) and comparison with related Actinobacteria. Stand Genomic Sci 12:10. https://doi.org/10.1186/s4079 3-016-0217-z

Cydzik-Kwiatkowska A, Zielinska M (2016) Bacterial communities in full-scale wastewater treatment systems. World J Microbiol Biotechnol 32(4):8. https://doi.org/10.1007/s11274-016-2012-9

Daims H, Lebedeva EV, Pjevac P, Han P, Herbold C, Albertsen M, Jehmlich N, Palatinszky M, Vierheilig J, Bulaev A, Kirkegaard RH, von Bergen M, Rattei T, Bendinger B, Nielsen PH, Wagner M (2015) Complete nitrification by Nitrospira bacteria. Nature 528(7583):20. https://doi.org/10.1038/natur e16461

Ding XC, Lu X, Ding XF, Wu B, Wang DP, Huang L, Wang XL, Tan YF, Zhang XX, Liu $B(2017)$ The total and functional bacterial community of nitrogen removal in the SND ditches. Int Biodeterior Biodegrad 118:102-109. https ://doi.org/10.1016/j.ibiod.2016.12.017

Edgar RC (2004) MUSCLE: multiple sequence alignment with high accuracy and high throughput. Nucleic Acids Res 32(5):1792-1797. https://doi. org/10.1093/nar/gkh340

Edgar RC (2010) Search and clustering orders of magnitude faster than BLAST. Bioinformatics 26(19):2460-2461. https://doi.org/10.1093/bioinformatics/ btq461

Fadrosh DW, Ma B, Gajer P, Sengamalay N, Ott S, Brotman RM, Ravel J (2014) An improved dual-indexing approach for multiplexed 16S rRNA gene sequencing on the Illumina MiSeq platform. Microbiome 2:7. https://doi. org/10.1186/2049-2618-2-6

Fernandez N, Sierra-Alvarez R, Amils R, Field JA, Sanz JL (2009) Compared microbiology of granular sludge under autotrophic, mixotrophic and heterotrophic denitrification conditions. Water Sci Technol 59(6):1227-1236. https://doi.org/10.2166/wst.2009.092

Fierer N, Hamady M, Lauber CL, Knight R (2008) The influence of sex, handedness, and washing on the diversity of hand surface bacteria. Proc Natl Acad Sci USA 105(46):17994-17999. https://doi.org/10.1073/pnas.08079 20105

Fitzgerald CM, Comejo P, Oshlag JZ, Noguera DR (2015) Ammonia-oxidizing microbial communities in reactors with efficient nitrification at lowdissolved oxygen. Water Res 70:38-51. https://doi.org/10.1016/j.watre s.2014.11.041

Flowers JJ, Cadkin TA, McMahon KD (2013) Seasonal bacterial community dynamics in a full-scale enhanced biological phosphorus removal plant. Water Res 47(19):7019-7031. https://doi.org/10.1016/.watres.2013.07.054

Foss S, Harder J (1998) Thauera linaloolentis sp. nov. and Thauera terpenica sp. nov., isolated on oxygen-containing monoterpenes (linalool, menthol, and eucalyptol) and nitrate. Syst Appl Microbiol 21(3):365-373

Gutierrez T, Green DH, Nichols PD, Whitman WB, Semple KT, Aitken MD (2013) Polycyclovorans algicola gen. nov., sp nov., an aromatic-hydrocarbon-degrading marine bacterium found associated with laboratory cultures of marine phytoplankton. Appl Environ Microbiol 79(1):205-214. https://doi.org/10.1128/aem.02833-12

Hien TTN, Le VQ, Hansen AA, Nielsen JL, Nielsen PH (2011) High diversity and abundance of putative polyphosphate-accumulating Tetrasphaerarelated bacteria in activated sludge systems. FEMS Microbiol Ecol 76(2):256-267. https://doi.org/10.1111/j.1574-6941.2011.01049.x

Hu M, Wang XH, Wen XH, Xia Y (2012) Microbial community structures in different wastewater treatment plants as revealed by 454 -pyrosequencing analysis. Bioresour Technol 117:72-79. https://doi.org/10.1016/j.biort ech.2012.04.061

Hug T, Ziranke M, Siegrist H (2005) Dynamics of population and scumming on a full-scale wastewater treatment plant in Switzerland. Acta Hydrochim Hydrobiol 33(3):216-222. https://doi.org/10.1002/aheh.200400570

Ibarbalz FM, Orellana E, Figuerola ELM, Erijman L (2016) Shotgun metagenomic profiles have a high capacity to discriminate samples of activated sludge according to wastewater type. Appl Environ Microbiol 82(17):5186-5196. https://doi.org/10.1128/aem.00916-16

Isazadeh S, Jauffur S, Frigon D (2016) Bacterial community assembly in activated sludge: mapping beta diversity across environmental variables. Microbiologyopen 5(6):1050-1060. https://doi.org/10.1002/mbo3.388

Ji B, Yang K, Zhu L, Jiang Y, Wang HY, Zhou J, Zhang HN (2015) Aerobic denitrification: a review of important advances of the last 30 years. Biotechnol Bioproc Eng 20(4):643-651. https://doi.org/10.1007/s12257-015-0009-0

Jiang XT, Guo F, Zhang T (2016) Population dynamics of bulking and foaming bacteria in a full-scale wastewater treatment plant over five years. Sci Rep 6:9. https://doi.org/10.1038/srep24180

Jin DC, Wang P, Bai ZH, Wang XX, Peng H, Qi R, Yu ZS, Zhuang GQ (2011) Analysis of bacterial community in bulking sludge using culture-dependent and -independent approaches. J Environ Sci 23(11):1880-1887. https:// doi.org/10.1016/s1001-0742(10)60621-3

Johnson DR, Lee TK, Park J, Fenner K, Helbling DE (2015) The functional and taxonomic richness of wastewater treatment plant microbial communities are associated with each other and with ambient nitrogen and carbon availability. Environ Microbiol 17(12):4851-4860. https://doi. org/10.1111/1462-2920.12429

Ju F, Guo F, Ye L, Xia Y, Zhang T (2014) Metagenomic analysis on seasonal microbial variations of activated sludge from a full-scale wastewater treatment plant over 4 years. Environ Microbiol Rep 6(1):80-89. https:// doi.org/10.1111/1758-2229.12110

Khan ST, Horiba Y, Yamamoto M, Hiraishi A (2002) Members of the family Comamonadaceae as primary poly(3-hydroxybutyrate-co3-hydroxyvalerate)-degrading denitrifiers in activated sludge as revealed by a polyphasic approach. Appl Environ Microbiol 68(7):3206-3214. https ://doi.org/10.1128/aem.68.7.3206-3214.2002

Kim YM (2013) Acclimatization of communities of ammonia oxidizing bacteria to seasonal changes in optimal conditions in a coke wastewater treatment plant. Bioresour Technol 147:627-631. https://doi.org/10.1016/j. biortech.2013.08.062

Lanham AB, Oehmen A, Saunders AM, Carvalho G, Nielsen PH, Reis MAM (2013) Metabolic versatility in full-scale wastewater treatment plants performing enhanced biological phosphorus removal. Water Res 47(19):7032-7041. https://doi.org/10.1016/j.watres.2013.08.042

Liang YH, Li D, Zhang XJ, Zeng HP, Yang Z, Cui SM, Zhang J (2014) Nitrogen removal and microbial characteristics in CANON biofilters fed with different ammonia levels. Bioresour Technol 171:168-174. https://doi. org/10.1016/j.biortech.2014.08.072

Liang HB, Ye DD, Li P, Su TT, Wu JG, Luo LX (2016) Evolution of bacterial consortia in an integrated tannery wastewater treatment process. RSC Adv 6(90):87380-87388. https://doi.org/10.1039/c6ra19603a

Liu Y, Zhang T, Fang HHP (2005) Microbial community analysis and performance of a phosphate-removing activated sludge. Bioresour Technol 96(11):1205-1214. https://doi.org/10.1016/j.biortech.2004.11.003

Liu T, Ahn H, Sun WM, McGuinness LR, Kerkhof LJ, Haggblom MM (2016) Identification of a Ruminococcaceae species as the Methyl tert-Butyl Ether (MTBE) degrading bacterium in a methanogenic consortium. Environ Sci Technol 50(3):1455-1464. https://doi.org/10.1021/acs.est.5b04731

Liu QF, Singh VP, Fu ZM, Wang J, Hu L (2017) An anoxic-aerobic system for simultaneous biodegradation of phenol and ammonia in a sequencing batch reactor. Environ Sci Poll R 24(12):11789-11799. https://doi. org/10.1007/s11356-017-8840-9 
Lu HJ, Chandran K, Stensel D (2014) Microbial ecology of denitrification in biological wastewater treatment. Water Res 64:237-254. https://doi. org/10.1016/j.waters.2014.06.42

Ma Q, Qu YY, Shen WL, Zhang ZJ, Wang JW, Liu ZY, Li DX, Li HJ, Zhou JT (2015) Bacterial community compositions of coking wastewater treatment plants in steel industry revealed by Illumina high-throughput sequencing. Bioresour Technol 179:436-443. https://doi.org/10.1016/j.biort ech.2014.12.041

Mao YJ, Zhang XJ, Xia X, Zhong HH, Zhao LP (2010) Versatile aromatic compound-degrading capacity and microdiversity of Thauera strains isolated from a coking wastewater treatment bioreactor. J Ind Microbiol Biotechnol 37(9):927-934. https://doi.org/10.1007/s10295-010-0740-7

Marks CR, Stevenson BS, Rudd S, Lawson PA (2012) Nitrospira-dominated biofilm within a thermal artesian spring: a case for nitrification-driven primary production in a geothermal setting. Geobiology 10(5):457-466. https://doi.org/10.1111/j.1472-4669.2012.00335.x

Martinez-Lavanchy PM, Chen Z, Lunsmann V, Marin-Cevada V, Vilchez-Vargas R, Pieper DH, Reiche N, Kappelmeyer U, Imparato V, Junca H, Nijenhuis I, Muller JA, Kuschk P, Heipieper HJ (2015) Microbial toluene removal in hypoxic model constructed wetlands occurs predominantly via the ring monooxygenation pathway. Appl Environ Microbiol 81(18):6241-6252. https://doi.org/10.1128/aem.01822-15

McLellan SL, Huse SM, Mueller-Spitz SR, Andreishcheva EN, Sogin ML (2010) Diversity and population structure of sewage-derived microorganisms in wastewater treatment plant influent. Environ Microbiol 12(5):1376. https ://doi.org/10.1111/j.1462-2920.2010.02204.x

Mielczarek AT, Nguyen HTT, Nielsen JL, Nielsen PH (2013) Population dynamics of bacteria involved in enhanced biological phosphorus removal in danish wastewater treatment plants. Water Res 47(4):1529-1544. https://doi. org/10.1016/j.watres.2012.12.003

Murphy EF, Cotter PD, Healy S, Marques TM, O'Sullivan O, Fouhy F, Clarke SF, O'Toole PW, Quigley EM, Stanton C, Ross PR, O'Doherty RM, Shanahan $F(2010)$ Composition and energy harvesting capacity of the gut microbiota: relationship to diet, obesity and time in mouse models. Gut 59(12):1635-1642. https://doi.org/10.1136/gut.2010.215665

Muszynski A, Tabernacka A, Milobedzka A (2015) Long-term dynamics of the microbial community in a full-scale wastewater treatment plant. Int Biodeterior Biodegrad 100:44-51. https://doi.org/10.1016/j.ibiod.2015.02.008

Ni B, Zhang Y, Chen DW, Wang BJ, Liu SJ (2013) Assimilation of aromatic compounds by Comamonas testosteroni: characterization and spreadability of protocatechuate 4,5-cleavage pathway in bacteria. Appl Microbiol Biotechnol 97(13):6031-6041. https://doi.org/10.1007/s00253-012-4402-8

Nielsen PH, Mielczarek AT, Kragelund C, Nielsen JL, Saunders AM, Kong YH, Hansen AA, Vollertsen J (2010) A conceptual ecosystem model of microbial communities in enhanced biological phosphorus removal plants. Water Res 44(17):5070-5088. https://doi.org/10.1016/.watres.2010.07.036

Orhon D, Babuna FG, Karahan O (2009) Industrial wastewater treatment by activated sludge. IWA Publishing, London

Oshiman K, Tsutsumi Y, Nishida T, Matsumura Y (2007) Isolation and characterization of a novel bacterium, Sphingomonas bisphenolicum strain AO1, that degrades bisphenol A. Biodegradation 18(2):247-255. https://doi. org/10.1007/s10532-006-9059-5

Panda AK, Bisht SS, De Mandal S, Kumar NS (2016) Bacterial and archeal community composition in hot springs from Indo-Burma region, North-east India. AMB Express 6:12. https://doi.org/10.1186/s13568-016-0284-y

Paul S, Cortez Y, Vera N, Villena GK, Gutierrez-Correa M (2016) Metagenomic analysis of microbial community of an Amazonian geothermal spring in Peru. Genomics Data 9:63-66. https://doi.org/10.1016/j.gdata.2016.06.013

Qian PY, Wang Y, Lee OO, Lau SCK, Yang JK, Lafi FF, Al-Suwailem A, Wong TYH (2011) Vertical stratification of microbial communities in the red sea revealed by 16 S rDNA pyrosequencing. ISME J 5(3):507-518. https://doi. org/10.1038/ismej.2010.112

Qian GS, Li L, Hu XM, Yu X, Ye LL (2017) Enhancement of the biodegradability of activated sludge by the electric-coagulation multistage $\mathrm{A} / \mathrm{O}$ membrane bioreactor treating low $\mathrm{C} / \mathrm{N}$ industrial wastewater. Int Biodeterior Biodegrad 125:1-12. https://doi.org/10.1016/j.ibiod.2017.08.004

Reeder J, Knight R (2010) Rapidly denoising pyrosequencing amplicon reads by exploiting rank-abundance distributions. Nat Methods 7(9):668-669. https://doi.org/10.1038/nmeth0910-668b

Robinson T, McMullan G, Marchant R, Nigam P (2001) Remediation of dyes in textile effluent: a critical review on current treatment technologies with a proposed alternative. Bioresour Technol 77(3):247-255. https://doi. org/10.1016/s0960-8524(00)00080-8

Roesch LF, Fulthorpe RR, Riva A, Casella G, Hadwin AKM, Kent AD, Daroub SH, Camargo FAO, Farmerie WG, Triplett EW (2007) Pyrosequencing enumerates and contrasts soil microbial diversity. ISME J 1(4):283-290. https:// doi.org/10.1038/ismej.2007.53

Saunders AM, Albertsen M, Vollertsen J, Nielsen PH (2016) The activated sludge ecosystem contains a core community of abundant organisms. ISME J 10(1):11-20. https://doi.org/10.1038/ismej.2015.117

Schloss Patrick D, Dirk Gevers L, Westcott S (2011) Reducing the effects of PCR amplification and sequencing artifacts on 16S rRNA-based studies. PLoS ONE 6(12):14

Sharma A, Paul D, Dhotre D, Jani K, Pandey A, Shouche YS (2017) Deep sequencing analysis of bacterial community structure of Soldhar hot spring, India. Microbiology 86(1):136-142. https://doi.org/10.1134/s0026 261717010118

Shchegolkova NM, Krasnov GS, Belova AA, Dmitriev AA, Kharitonov SL, Klimina KM, Melnikova NV, Kudryavtseva AV (2016) Microbial community structure of activated sludge in treatment plants with different wastewater compositions. Front Microbiol 7:15. https://doi.org/10.3389/fmicb .2016 .00090

Shinoda Y, Sakai Y, Uenishi H, Uchihashi Y, Hiraishi A, Yukawa H, Yurimoto $\mathrm{H}$, Kato N (2004) Aerobic and anaerobic toluene degradation by a newly isolated denitrifying bacterium, Thauera sp. strain DNT-1. Appl Environ Microbiol 70(3):1385-1392. https://doi.org/10.1128/ aem.70.3.1385-1392.2004

Thomsen TR, Kong Y, Nielsen PH (2007) Ecophysiology of abundant denitrifying bacteria in activated sludge. FEMS Microbiol Ecol 60(3):370-382. https ://doi.org/10.1111/j.1574-6941.2007.00309.x

Tomasek A, Staley C, Wang P, Kaiser T, Lurndahl N, Kozarek JL, Hondzo M, Sadowsky MJ (2017) Increased denitrification rates associated with shifts in prokaryotic community composition caused by varying hydrologic connectivity. Front Microbiol 8:12. https://doi.org/10.3389/fmicb.2017.02304

Tuncal T, Pala A, Uslu O (2009) Determination of microbial response to seasonal variations of wastewater composition in the IZMIR wastewater treatment plant. Fresenius Environ Bull 18(11):2114-2122

Valentin-Vargas A, Toro-Labrador G, Massol-Deya AA (2012) Bacterial community dynamics in full-scale activated sludge bioreactors: operational and ecological factors driving community assembly and performance. PLOS ONE 7(8):12. https://doi.org/10.1371/journal.pone.0042524

Veeravalli SS, Lalman JA, Chaganti SR, Heath DD (2017) Continuous hydrogen production using upflow anaerobic sludge blanket reactors: effect of organic loading rate on microbial dynamics and $\mathrm{H}-2$ metabolism. J Chem Technol Biotechnol 92(3):534-541. https://doi.org/10.1002/jctb.5032

Vishnivetskaya TA, Fisher LS, Brodie GA, Phelps TJ (2013) Microbial communities involved in biological ammonium removal from coal combustion wastewaters. Microb Ecol 66(1):49-59. https://doi.org/10.1007/s0024 8-012-0152-5

Wagner M, Loy A (2002) Bacterial community composition and function in sewage treatment systems. Curr Opin Biotechnol 13(3):218-227. https:// doi.org/10.1016/s0958-1669(02)00315-4

Wan CY, De Weyer H, Diels L, Thoeye C, Liang JB, Huang LN (2011) Biodiversity and population dynamics of microorganisms in a full-scale membrane bioreactor for municipal wastewater treatment. Water Res 45(3):11291138. https://doi.org/10.1016/j.watres.2010.11.008

Wang XH, Hu M, Xia Y, Wen XH, Ding K (2012) Pyrosequencing analysis of bacterial diversity in 14 wastewater treatment systems in china. Appl Environ Microbiol 78(19):7042-7047. https://doi.org/10.1128/aem.01617-12

Wang P, Yu ZS, Zhao JH, Zhang HX (2016) Seasonal changes in bacterial communities cause foaming in a wastewater treatment plant. Microb Ecol 71(3):660-671. https://doi.org/10.1007/s00248-015-0700-x

Wells GF, Park HD, Eggleston B, Francis CA, Criddle CS (2011) Fine-scale bacterial community dynamics and the taxa-time relationship within a full-scale activated sludge bioreactor. Water Res 45(17):5476-5488. https ://doi.org/10.1016/j.watres.2011.08.006

Xu D, Liu ST, Chen Q, Ni JR (2017) Microbial community compositions in different functional zones of carrousel oxidation ditch system for domestic wastewater treatment. AMB Express 7:13. https://doi.org/10.1186/s1356 8-017-0336-y

Yang C, Zhang W, Liu RH, Li Q, Li BB, Wang SF, Song CJ, Qiao CL, Mulchandani A (2011) Phylogenetic diversity and metabolic potential of activated sludge 
microbial communities in full-scale wastewater treatment plants. Environ Sci Technol 45(17):7408-7415. https://doi.org/10.1021/es2010545

Ye L, Zhang T, Wang TT, Fang ZW (2012) Microbial structures, functions, and metabolic pathways in wastewater treatment bioreactors revealed using high-throughput sequencing. Environ Sci Technol 46(24):13244-13252. https://doi.org/10.1021/es303454k

Ye TR, Cai HY, Liu X, Jiang HL (2016) Dominance of Oscillospira and Bacteroides in the bacterial community associated with the degradation of high-concentration dimethyl sulfide under iron-reducing condition. Ann Microbiol 66(3):1199-1206. https://doi.org/10.1007/s13213-016-1207-5

Yi Z, Ye R, Haiyun W, Can L, Min C (2015) Study on identification and characterization of PTA-degrading bacterial strains. Environ Sci Manag 40(3):4 (in Chinese)

Yoon DN, Park SJ, Kim SJ, Jeon CO, Chae JC, Rhee SK (2010) Isolation, characterization, and abundance of filamentous members of Caldilineae in activated sludge. J Microbiol 48(3):275-283. https://doi.org/10.1007/ s12275-010-9366-8
Zhang T, Shao MF, Ye L (2012) 454 Pyrosequencing reveals bacterial diversity of activated sludge from 14 sewage treatment plants. ISME J 6(6):11371147. https://doi.org/10.1038/ismej.2011.188

Zhang LL, Zhang C, Hu CZ, Liu HJ, Qu JH (2015) Denitrification of groundwater using a sulfur-oxidizing autotrophic denitrifying anaerobic fluidized-bed MBR: performance and bacterial community structure. Appl Microbiol Biotechnol 99(6):2815-2827. https://doi.org/10.1007/s00253-014-6113-9

Zhang B, Xu XY, Zhu L (2017) Structure and function of the microbial consortia of activated sludge in typical municipal wastewater treatment plants in winter. Sci Rep 7:11. https://doi.org/10.1038/s41598-017-17743-x

Zielinska M, Rusanowska P, Jarzabek J, Nielsen JL (2016) Community dynamics of denitrifying bacteria in full-scale wastewater treatment plants. Environ Technol 37(18):2358-2367. https://doi.org/10.1080/09593330.2016.11503 50

\section{Submit your manuscript to a SpringerOpen ${ }^{\circ}$ journal and benefit from:}

- Convenient online submission

- Rigorous peer review

- Open access: articles freely available online

- High visibility within the field

- Retaining the copyright to your article

Submit your next manuscript at $\boldsymbol{\nabla}$ springeropen.com 